\title{
Halide Edib Hampstead'de: İngilizlerin İşgalci ve Ev Sahibi Olarak Temsili
}

\section{Halide Edib in Hampstead: Representations of the English as Occupier and the Host}

\author{
Nagihan Haliloğlu ${ }^{1}[$
}

'Dr. Öğr. Üyesi, İbn Haldun Üniversitesi, İnsan ve Toplum Bilimleri Fakültesi, Karşılaştırmalı Edebiyat Bölümü, İstanbul, Türkiye

ORCID: N.H. 0000-0003-4958-6084

Sorumlu yazar/Corresponding author: Nagihan Haliloğlu,

İbn Haldun Üniversitesi, İnsan ve Toplum Bilimleri Fakültesi, Karşılaştırmalı Edebiyat Bölümü, İstanbul, Türkiye

E-mail: nagihan.haliloglu@ihu.edu.tr

Başvuru/Submitted: 04.03.2019

Revizyon Talebi/Revision Requested: 13.05.2019 Son Revizyon/Last Revision Received: 20.05.2019 Kabul/Accepted: 21.05.2019

Online Yayın/Published Online: 28.06.2019

\section{Attf/Citation:}

Haliloglu, N. (2019). Halide Edib Hampstead'de: İngilizlerin işgalci ve ev sahibi olarak temsili. TUDED 59(1), 67-88

https://doi.org/10.26650/TUDED2019-0004

\section{ÖZET}

Bu makale Halide Edib [Adıvar]'ın (1884-1964) İngiltere ile olan ilişkisini yazılarındaki ev sahibi, misafir ve işgalci kavramları üzerinden inceleyecektir. Halide Edib'in İngiltere ile olan ilişkisinde bu kavramların hem tarihi hem de söylemsel karşılıkları vardır. Bu kavramların söylemsel manalarına Haswell ve Haswell'in geliştirdiği misafirperverlik ve yazarlık çerçevesinden bakılacaktır.

Haswell ve Haswell bu çerçeveyi sömürge ilişkileri üzerinden inşa etmiş olsa da, tespitlerini sömürge ilişkisi olmayan durumlarda da gözlemlemek mümkündür. İngiliz ordusunun İstanbul işgaline tanıklık etmiş, yazılarında Hindistan'a dair örnekler veren Halide Edib'in eserlerindeki İngiliz figürü genel edebiyat tarihinden tanıdığımız sömürgeci figürüyle örtüşmektedir. Yazarın en sevimsiz İngiliz karakteri olan Ateşten Gömlek'teki gazeteci Mr. Cook sömürgeci zihniyetini temsil eder. Halide Edib'in kahramanı Ayşe de okuyucuya bu sömürgeci söyleme nasıl karşılık verilmesi gerektiğini gösterir. Halide Edib böylelikle bir çeșit "metin ile karşılık verme" formülü geliştirmiş olur. Yazarın bu formülü elbette kendi ev sahibi, misafir, işgalci anlayışı ve yine kendi enternasyonalizm ve milliyetçilik anlayışı etrafında gelişir. Kariyerinin bir döneminde İngiltere'de sürgün hayatı geçirmek zorunda Halide Edib'in hayatındaki işgalci figürüne misafir olması bu kategorileri tekrar tekrar gözden geçirmesine sebep olur. İngiltere'deyken işgal anılarını İngilizce kaleme alan Halide Edib Türkiye’ye döndüğünde bu sefer İngilizleri Türklere anlatma görevini üstlenir. Bir İngiliz Edebiyatı okuyucusu ve Türk Edebiyatı yazarı olarak Halide Edib Haswell ve Haswell'in geliştirdiği ev sahibi-yazar ve misafir-okuyucu kategorilerini ters yüz eder.

Anahtar Kelimeler: Halide Edib, İngiltere, misafirperverlik, sürgün, işgal

\section{ABSTRACT}

This article traces Halide Edib's interactions with England and the English and the ways in which she represented them in writing. I argue her representations were governed by conceptions of host, guest and occupier- a triumvirate of relations that is informed by Haswell and Haswell's understanding of hospitality and authoring. I examine how Halide Edib's understanding of occupier and host, nationalism and internationalism were shaped as she witnessed the British occupation of Istanbul, as she set about writing columns for the independence of Turkey, maintaining her cosmopolitan approach. Halide Edib expressed her views of the English in fiction, memoir, and newspaper article format, dealing with different aspects of a nation in different contexts. The first impressions of England she had in 1909 remained with Halide Edib for a long time, as evidenced in the newspaper articles she wrote in 1939. Both during her earlier visit and years in exile, England introduced her to an international world of letters which she embraced for the rest of her life, and which led her to lecture in places such as the US and India. This article investigates the various methods she uses in describing the English throughout her career, in a way that both consolidates her initial impressions and recognizes the changing context.

Keywords: Halide Edib, England, hospitality, exile, occupation 


\section{EXTENDED ABSTRACT}

This paper considers Halide Edib [Adıvar]'s (1884-1964) writing through her relationship with England, as her narratives straddle between the categories of host, guest and occupier. These categories have historical as well as discursive meanings in Halide Edib's relationship with England. Halide Edib is a figure whose life runs through the end of the Ottoman Empire to the first years of the Turkish republic. She was a writer, warrior and politician who fell out with Atatürk and spent the years of 1926-1936 in exile abroad, mostly in England. Halide Edib's father was a proponent of the Anglo-Saxon model of education and employed an Anglo-Indian governess, and her intellectual development was bilingual from the start. Halide Edib's later records in writing her interactions with the English at this early age, followed by her impressions of London in 1909 as a guest, and then in the 1920 as occupiers in Istanbul. This is what complicates the categories of host, guest and occupier. I delineate the discursive meanings attached to these categories using Haswell and Haswell's understanding of hospitality and authoring. Although their framework is a colonial one, Haswell and Haswell's methodology applies to Halide Edib's writing in so far as she both experiences Istanbul's occupation by the British and is often inspired by the Indian example. I argue that as a reader of English literature and writer of Turkish literature, Halide Edib transformed the host-author, guest-reader complexes that Haswell and Haswell so fruitfully map out. Her most unsympathetic English character, the journalist Mr Cook in Ateşten Gömlek represents the English colonial mind-set, and Halide Edib's heroine Ayşe reveals to us how one ought to fight this colonialist discourse: thus Halide Edib also formulates a nascent mode of 'writing back'. This mode is very much connected to her understanding of occupier and host, nationalism and internationalism. Her mode of 'writing back' was shaped as she witnessed the British occupation Istanbul and wrote columns for the independence of Turkey, meanwhile maintaining her cosmopolitan approach. I argue that when we consider the discourse she uses in her writing from the start, there is no irony in the fact that it was in London where she found a literary home when she had to leave Turkey. Her writing insists that host-guest relations become meaningless under occupation, and that only during peacetime can nations and individuals develop meaningful relationships. Halide Edib's work reminds us to consider host- guest- occupier relationships in two registers: the relationship between states and the relationship between individuals. This becomes very apparent when she returns to Turkey to write newspaper articles under the heading 'England and the English' in which she reports her personal experience of England, without ever mentioning the occupation of Istanbul in the 20s. She prefaces her observations and encyclopaedic knowledge of England with the caveat that one can never generalize the characteristics of a nation. Still, her observation of English institutions gives her a model through which one can assess Turkey's attempts at becoming a new state and nation. It is particularly the English Parliament that comes across as a talking point and inspiration in her non-fiction. In her memoir The Turkish Ordeal, which is an indictment of the British occupation's violence and Mustafa Kemal's later despotic tendencies, it is still the image of the British Parliament that she and her husband evoke when 
they are discussing how best to respond to the closure of the Ottoman parliament. On her return to Turkey, not only does she inform the general public about the English through her newspaper columns, but also becomes the reader-occupier in the English language as founder of the English Literature department at Istanbul University. Through her representation of the English Halide Edib gets her message across about occupation, colonialism, but also the importance of institutions for a country to be successful. She uses the categories of host, guest and occupier in her narratives variously while she is perfectly aware of the role she has to presume in different points in her life. And these roles have been as various as cosmopolitan Ottoman writer, member of the international republic of letters, and an intellectual that translates between cultures. 


\section{GÍRİŞ}

1884'te İstanbul'da doğan Halide Edib, edebî hayatı Osmanlı İmparatorluğu döneminde başlayıp Cumhuriyet döneminde devam eden yazarlardan biridir. Halide Edib bu farklı dönemlerde yazar, öğretmen, politikacı olarak görev yapmış ve her iki dönemde de aykırı fikirlerinden dolayı bazen danışılan, bazen de tehlikeli görülen bir entelektüel olmuştur. Halide Edib bu "tehlikeli" yanı yüzünden hem Osmanlı hem de Cumhuriyet dönemlerinde bir çeşit sürgün hayatı sürmek zorunda kalır. İstanbul'da başlayan yazarlığının bir meyvesi olarak yurtdışında pek çok okur ve arkadaş edinen Halide Edib, Türkiye'yi terk etmek zorunda kaldığında yine uluslararası edebiyat dünyasında edindiği bu arkadaşların davetleriyle yurtdışında yer edinmeyi başarır. Bu makale uzunca süren sürgün dönemlerinden birini, 19251928 yıllarını Londra' da geçiren Halide Edib'in İngiltere ve İngilizleri yazınında nasıl tasvir ettiğini inceleyecek ve bu tasvirlerin metinlerde nasıl ev sahibi-misafir-işgalci kategorileri arasında dolaştığının izini sürecektir. Bu üçlü düzlemin tarihsel bir karşılığı olduğu gibi, Halide Edib'in eserlerinde gözlemleyebileceğimiz söylemsel ve edebî bir karşılığı da vardır. Bu söylemsel ve edebî izlek özellikle Ateşten Gömlek ve The Turkish Ordeal kitapları, daha sonra da 1939 yılında yazdığı Akşam gazetesi makaleleri üzerinden takip edilecektir. Halide Edib'in Doğu-Batı ve modernleşme meselelerine bakışı şimdiye kadar esaslı eserlerde ele alınmıştır. Bu çalışma yazarın hem modernleşme, hem de Doğu-Batı ilişkileri tarihlerinde özel bir yeri olan İngiltere ile olan ilişkisinin eserlerine nasıl yansıdığını ve bu yansımanın şekil verdiği söylem ve anlatı tekniğini incelemektedir.

İngiltere ve Türkiye arasındaki ilişki hiçbir zaman bir sömürge ilişkisine dönüşmese de Halide Edib'in İngiliz tasavvuru İngiliz sömürge tarihi bilinci merceğinden geçerek oluşmuştur. Halide Edib için Hindistan İngilizlerin Avrupa dışındaki uluslarla olan ilişkilerine ışı k tutan bir deneyimdir ve İngiltere'yle ilgili yazılarında İngiliz yönetimindeki Hindistan'a sık sık gönderme yapar. Bu yüzden bu makalede sömürge ilişkileri çerçevesinde "ev sahipliği” ve “yazarlık” üzerine çalışmış olan Richard ve Janis Haswell'in kullandıkları kavramlardan yararlanacağım. Haswell ve Haswell'in Hospitality and Authoring (2010) adlı kitaplarında çerçevesini çizdikleri “ev sahipliği” ve "yazarlık” kavramlarının ikisi de Halide Edib'in İngiltere’yle olan ilişkisini ve bu ilişkiyi yazınına nasıl aktardığını anlamamıza yardımcı olacaktır. Haswell ve Haswell kitaplarında özellikle Avrupa tarihinde ev sahibi ve misafir kavramlarının nasıl geliştiğinin üstünde durduktan sonra, misafirperverlik kurallarının okur ve yazar arasındaki ilişkiyi nasıl etkilediğinden veya etkilemesi gerektiğinden bahseder. Okurlar metinlere birer misafir olarak konuk olur, yazarlar da onlara ev sahipliği ederler. "Kitap, metin bir potansiyelin ve tekilliğin birleştiği yeni fikirlere açık bir mekândır. Yazar ev sahibi, okur da misafir olarak başlar: Kitap da potansiyelin gerçekleştiği ama hiçbir zaman tükenmediği bir yurt olur." (Haswell ve Haswell, 2010, 13) Haswell ve Haswell'in kavramsallaştırmasında fiziksel ve söylemsel "yurt”lar -ülkeler ve metinler- sürekli yer değiştirir ve birbirleri için mecaz olarak kullanılır. Halide Edib de erken yaşta İngiltere'nin bir "okur"u yani bu manada "misafïr"i olmuş ve yine bu erken yaşta ülke ve yazar arasında bu çerçevede bir ilişki oluşmuştur. 
Haswell ve Haswell ev sahibi ve misafirin hemen hemen tüm kültürlerde tanınan bir hukuk kesbettiğini ve bu hukukun karşılıklı alışverişe, hatta hediyeleşmeye dayalı olduğunun altını çizer. (Haswell ve Haswell, 2010, 5) Okur ve yazar arasındaki güç ilişkisinin dengesiz olduğu durumlarda, örneğin acımasız bir eleştirmen söz konusu olduğunda, bu hukukun dışına çıkıldığı görülür. Bu güç dengesinin siyasi bir boyutu olduğu yerlerde misafirlik-ev sahipliği kuralları hepten çiğnenip roller bile değişebilir. Misafir, takındığı tavırla işgalciye dönüşüp, ev sahipliği pâyesini “yerli”nin elinden alabilir. "Ev sahibi-yazar ve okur-misafir ikilileri misafirin metni işgal edip ev sahibiymiş gibi kontrolü ele geçirmesiyle ters yüz olur. Sömürge ilişkileri kapsamında eleştiriden kastımız budur." (Haswell ve Haswell, 2010, 22) Haswell ve Haswell, Jacques Derrida ve Mireille Rosello'nun ev sahibi ve misafir tartışmalarından yola çıkarak, bu kategorilerin sömürge ilişkileri içerisinde nasıl bir anlam kazandığını daha detaylı olarak şöyle değerlendirir:

Avrupa yayılma politikalarının askerî, ekonomik ve misyonerlik itici gücüyle yabancı ülkelere gidenler gittikleri yerlerde misafir olarak başladıkları yaşantılarını kısa bir süre sonra ev sahipliği rolünü ele geçirerek devam ettiler. Bu topraklara sonradan gelenler işgalci ya da sömürgeci oldu [...] Sömürge çerçevesindeki ev sahipliği, ev sahipliğinin ahlaki çerçevesini ve kurallarını hiçe sayar: Bunun sebebi ev sahibiyle misafirin rolleri değiştirmiş olması değildir. Asıl sebep karşılıklı bir alışverişin olmayışı ve rollerin hakkaniyetli bir şekilde tekrar tanımlanmamış olmasıdır. Yeni ev sahibi bir zamanlar ev sahibi olan ve artık kendi topraklarında misafir olan yerlileri yiyip yutar. (Haswell ve Haswell, 2010, 21)

Okuyucular olarak hepimizin potansiyel işgalciler olabileceğimiz konusunda bizi uyarmış olan Haswell ve Haswell, sömürge çerçevesindeki ev sahibi, misafir ve işgalci işlevlerine dikkatimizi çekerek, bizi bu ilişkilerin söylemsel boyutlarını düşünmeye davet eder.

Halide Edib'in İngiltere ile olan ilişkisi okur-misafir olarak başlamıştır. Daha sonra İngiliz dergilerine yolladığı yazılarla yazar-ev sahibi rolünü üstlenmiştir. İngilizlerin İstanbul'u işgaliyle Haswell ve Haswell'in yukarıda tasvir ettiği gibi "yerli” olan Halide Edib'in hakkı olan ev sahipliği hem fiziksel, hem de söylemsel olarak elinden alınmıştır. Yazar daha sonra İngiltere'de fiziksel olarak misafir olmuş ve bir manada “ev sahibiymiş gibi” İngiliz dilini kullanarak İstanbul işgalinin hikâyesini yazmıştır. Halide Edib’in daha sonraları hem İngiltere hakkında makaleler hem de Ingiliz Edebiyatı Tarihi yazmış olması Haswell ve Haswell'in işaret ettiği "kontrolü ele geçirme" olarak okunabilir. Bu durumda Halide Edib bir manada İngiliz tarihini "işgal” etmiş olur. İngiliz edebiyatı okuyucusu, Türk edebiyatı yazarı, İngiliz edebiyatı tarihçisi olarak Halide Edib ev sahibi-yazar ve okur-misafir ilişkilerini hem tecrübe etmiş hem de dönüştürmüştür.

İngiltere ve Halide Edib’in birbirlerine karşı nasıl ev sahipleri ve/veya misafirler olduklarını anlamak için 29 Temmuz 1928 tarihli "A Woman Speaks for the New Turkey" (Yeni Türkiye'nin Sözcüsü Bir Kadın) başlıklı New York Times makalesinden başlayabiliriz. Gazeteci Claire Price Halide Edib'i şöyle tasvir eder: 
Halide Edib'in diğer oğlu şu anda Londra'da ekonomi okulunda okuyor. Anne ise 1924'den beri İngilizlerin arasında yaşıyor. 1920 yılında Anadolulu askerlerin tedarik ettiği bir kağnı arabasında kömür çuvallarının altına gizlenerek ellerinden kurtulduğu İngilizler. New York'a gitmeden birkaç gün önce bir ziyaretçi onu Londra'nın Hampstead semtinde ziyaret etti. Dairesinin duvarlarında, yeşil kadife üzerine sırmayla Kur'an'dan ayetlerin yazılı olduğu levhalar değil, Londra'da binlerce başka daireyi süsleyen esaslı Viktoryen resimler vardı. Türkiye'de genelde misafirlere ikram edilen Türk kahvesi ve tatlılar yerine, misafire çay ve sıcak İngiliz kurabiyesi ikram edildi. (New York Times, 1928, 29 Temmuz)

1928 senesine ait, Halide Edib'in nasıl bir ev sahibesi olduğuna dair bu resim yazarın İngiltere ve İngilizlerle olan ilişkisini gayet güzel özetlemektedir: Bir zamanlar onlardan kaçan yazar, şimdi çalışma masasını Londra'da kurmuştur. Bunu yaparken de oryantalist tahayyülün dışına çıkarak, evini bulunduğu ülkenin zevkine göre döşemiştir. Bu durum kaderin bir cilvesi gibi görünse de, Londra'nın Halide Edib için yazın hayatının başından beri önemli bir merkez olduğunu hatırlamak gerekir. Yazar ilk önce kısa bir süre için 1909 yılında, daha sonra 1925 'te tekrar, bu sefer uzun süreliğine İngiltere'ye geldiğinde kendini hararetli bir edebî hayatın içinde bulmuş, makaleler yazmış, konferanslar vermiş ve dönemin önemli İngiliz yazarlarıyla görüşmeler yapmıştır. Adnan Adıvar'ın Bilgi Cumhuriyeti Haberleri (1945) kitabının adında da gönderme yaptı̆̆g, bir çeşit "Bilgi Cumhuriyeti”nin bir parçası, PEN derneğinin bir üyesi olmuştur. Yukarıdaki resimde Halide Edib, Haswell ve Haswell'in tanımındaki sömürgeciler gibi yerlileri yurtlarından etmese de onların âdetlerini "yiyip yutmuş" olarak ev sahipliği yapmaktadır.

Her ne kadar Price, Halide Edib'in Londra'daki durumunu ironiyle anlatsa da yazarın kendisi Londra' daki varlığını böyle değerlendirmemiş, kendini ülkelerinin bağımsızlığına ve baskılara karşı gelmeye adamış uluslararası yazarların yolunun geçtiği bir şehirde yaşayan bir yazar olarak görmüştür. Nitekim Atatürk de kendisiyle fikir ayrılığına düştüğü için bir çeşit sürgün hayatı süren Halide Edib'in çelişkili görünen bu durumundan Türkiye'deki İngiltere temsilcisi Reginald Hoare'a "her zaman zarar vermek istediği ülkenin (yani İngiltere’nin) şimdi ona sığınak sunuyor oluşunu” garipsediğini söyler (Çalışlar, 2010, 344). Atatürk'ün Hoare'a olan bu serzenişi bize düşman ve müttefik çerçevesini iki farklı düzlemde düşünmemiz gerektiğini hatırlatır. Bu düzlemlerin biri devletler, yani İngiltere ve Türkiye, diğeri de bireyler arasındaki, yani Halide Edib ve edebî çevresi arasındaki ilişkileri kapsar. Devlet, birey, işgalci ve ev sahibi gibi düşman ve müttefik algımızda belirleyici rol oynayan kategoriler hem Halide Edib'in zamanında hem de günümüzde sürekli değişmekte ve birbirinin içine geçmektedir.

\section{Halide Edib’in Yazınında İngilizler}

Halide Edib'in İngiltere ile olan ilişkisi çocukluğunda başlamıştır. İpek Çalışlar biyografisinde Halide Edib'in bir saray görevlisi olan babasının kitaplardan ve dergilerden 
öğrendiği İngiliz çocuk yetiştirme tarzına göre yetiştirildiğinden bahseder. Bunun yanında Halide Edib'e bir de Anglo-Hint bir mürebbiye tutulur. İnci Enginün Halide Edib Adlvar'ın Eserlerinde Doğu Batı Meselesi adlı eserinde Halide Edib'in 'İngiliz terbiyesi' alırken yaşadıklarını şöyle yorumlar:

İngilizlere ve İngiliz terbiyesine hayran olan Edib Bey kızının giyimi ve beslenmesinde de İngiliz terbiyesini örnek almıştır. İngilizlerin büyüklüğünün sırrını, terbiye sistemlerinde bulur. Bu fikri sonraki yıllarda Halide Edib de paylaşacaktır. Raik'in annesi, Talim ve terbiye. Edib Bey ilk çocuğunu kitaplardan öğrendiği İngiliz usulünde yetiştirmeğe kararlıdır. (Enginün, 1978, 20)

Edib Bey'in kitaplardan uyguladığı bu yetiştirme tarzının zamanın İngiliz çocuklarının yetiştirilme tarzıyla ne kadar örtüştüğünü tespit etmek zor, fakat Halide Edib'in ilerleyen yıllarda İngilizlerle olan diyaloglarındaki doğallığının ve İngiliz kültürünü anlamadaki kıvraklığının nüvelerinin bu eğitimle atıldığını söylemek yanlış olmasa gerek. Edib Bey’in uyguladığ 1 bu rejim çocuk Halide'nin ne giyeceğini de belirler:

Kışın İngiliz işi kısa, lacivert elbise, yazın beyaz keten elbise giydirilen çocuğun, kolları ve bacakları daima çıplaktır. Bu anneanneyi daima çocuk soğuk alacak endişesine düşürür [...] Soğuk ve sıcak değil, fakat başka çocuklardan farklı olma küçük kıza ıstırap verir; zira o, kıyafetiyle dikkat çekmektedir. Başka çocukların giydikleri renkli, ipekli, kurdeleli elbiseleri, taktıkları incik boncuğu kıskanır [...] Beslenme ikinci önemli meseledir. Onun sınıfındaki ve yaşındaki Türk çocukları canlarının istediğini yedikleri halde, Halide Edib'e sadece et ve sebze, az miktarda ve yemek saatinde olmak üzere meyve verilir. Çocuk sütten nefret eder, her türlü meyveyi sever. Bu beslenme tarzı, günlük banyo ve gözlerine damlattıkları ilaç olmasa, babasının evinde oldukça mesuttur. (Enginün, 1978, 20-21)

Görünen o ki İstanbul'da yaşanılan İngiliz çocukluk Halide Edib için pek de kolay olmamıştır. Construction of Nationalism and Gender in Halide Edib's Autobiographical Writings adlı kitabında Zeynep Beril Saydun da bu "eğitim"in küçük Halide'ye nasıl zor geldiğinden bahseder (Saydun, 2008, 15-16).

Bu ilk senelerden sonra babası Halide Edib'i Üsküdar Amerikan Koleji'ne gönderir. Amerika da İngiltere gibi Halide Edib'in edebî ve entelektüel hayatında önemli bir rol oynayacaktır. Nitekim Halide Edib pek çok yazısında İngiliz ya da Amerikan yerine ikisini birden içeren Anglosakson kelimesini kullanır. İngiltere'de yaşadığı senelerde de yukarıdaki alıntıda görüldüğü gibi Amerikan basınıyla iletişim içinde olmuş (Forbes, 1926; Streit, 1928) ve ders vermek üzere Amerika'ya gitmiştir. Bir manada bu iki ülke hakkındaki izlenimleri birbirinin içine geçmiştir. Hatta yazılarının Amerika' da daha fazla yankı bulduğu söylenebilir. Bu makalede özellikle İngiltere ile olan ilişkisinin seçilmesinin sebebi yazarın çok daha küçük yaştan itibaren İngiliz edebiyatıyla tanışmış ve İngiltere ile olan ilişkisinin Amerika'yla olanla karşılaştırıldığında daha çeşitli evrelerden geçmiş olmasıdır. 
Yazar Üsküdar Amerikan Koleji'ndeki eğitimini tamamladıktan sonra gazete yazıları yazmaya başlar. Günün meseleleriyle yakından ilgilenen Halide Edib, Enginün'ün de belirttiği gibi Meşrutiyet fikrinin temsilcileriyle temas halindedir (Enginün, 1978, 9). Yazar kendisi de Meşrutiyet lehinde yazılar yazmış ve Batılılaşmanın nasıl gerçekleşmesi gerektiği konusunda kafa yormuştur. Yazar Batılılaşmadan önce Batı'nın ne olduğunu anlamak gerektiğine dikkat çeker ve ancak bu anlaşıldıktan sonra Batı'daki kültürel formaların adapte edilebileceğini düşünür (Enginün, 1978, 15) Nitekim bu sorular Halide Edib'in yazın hayatı boyunca ilgilendiği sorular olmuş, 1930'da sonunda Turkey Faces West adlı bir kitap yazmıștır.

Daha 1930'lara gelinmeden, Meşrutiyet'e giden dönemde ve hemen ardında İngiliz diline tamamen hakim olması hasebiyle İngilizce yazılar da kaleme alan Halide Edib'in yazıları yabancılar tarafından takip edilmeye başlanır. Bu Halide Edib'in İngiliz dilini kendine ev edinmesinin başlangıcıdır. Haswell ve Haswell'in terimleriyle söyleyecek olursak yazar İngiliz yazınında okur-misafirlikten ev sahibi-yazarlığa geçmiştir. Halide Edib'in günümüzde New Statesman olarak devam eden Nation dergisinde yayımlanan Osmanlı İmparatorluğu'nda kadınların eğitimi hakkındaki yazısını okuyan ve dönemin Londra entelijansiyasından bir isim olan Isobel Fry’la aralarında bir yazışma başlar. Bu yazışmada Halide Edib Fry’a Türk kadınlarının örtülü olmalarının eğitimleri açısından bir engel teşkil etmediğini, kadınların eğitiminde İngiliz modelinin takip edilmesini tercih ettiğini söyler (Durakbaşa, 2000, 191192). Bu yazışmadan çok etkilenen Fry İstanbul'u ziyaret eder, daha sonra da yazarı 1909 yılında Londra'ya davet eder. Yazıları yüzünden tehditler alan Halide Edib 31 Mart Vakası döneminde gelen bu davete icabet eder ve çocukken İngiliz mürebbiyeye ev sahipliği yapmış olan Halide Edib için ilk defa roller değişir: Yazar İngiltere'de misafir olmak üzere yola koyulur.

Halide Edib'in İngiltere'deyken ülkeyle ilgili gözlemleri hakkında bir şeyler yazdığına dair bir kayıt yoktur. Mektuplarından anlaşıldığı üzere bu ilk Londra seyahatinde, bir sene sonra, 1910'da yayımlayacağı Seviye Talip üzerinde çalışmıştır. Bitmekte olan bir evliliği tasvir ettiği bu romanının yayımlanmasından kısa süre sonra Halide Edib Zeki Salih'ten boşanır ve yazılarını Halide Salih yerine Halide Edib adıyla yayımlamaya başlar. Halide Edib'in adı, soyadı kanunuyla bir kez daha değişecektir. Halide Edib'in yazınında İngiltere'nin izini takip etme çabası bizi Seviye Talip’ten sonra yazdığı, yine mutsuz bir evlilik hikayesi olan Handan'a (1912) getirir. Handan'daki klinik depresyon geçiren kadın karakterler çeşitli Avrupa ülkelerinde tedavi edilir. Romanda Londra'da geçen bölümler vardır ama hiç İngiliz karakter olmadığı gibi hemen hemen hiç tasvir de yoktur. Londra, evliliklerinin bittiği gerçeğiyle yüzleşmeye çalışan karakterler ve belki aynı şekilde Halide Edib için bir sahnedir sadece. İlginç bir şekilde Halide Edib ilk İngiliz karakterlerini Ateşten Gömlek romanında, İngilizler Halide Edib'in hayatında işgalci rolü oynadıklarında kaleme alacaktır.

Halide Edib'in ilk olarak Birinci Dünya Savaşı sırasında gazetede tefrika edilen, daha sonra 1922 yılında yayımlanan Ateşten Gömlek romanı İngilizlerin İstanbul işgalini konu edinir. Roman iki sene sonra 1924'te New York'ta İngilizce olarak da yayımlanır. Ateşten Gömlek 
işgal İstanbul'unda tefrika edildiğinde Halide Edib on binlerce insana 1919 Sultanahmet Mitingi'nde hitap etmiş olan, Türk direniş hareketinin önemli isimlerinden biridir. Halide Edib'in İstanbul'dan Ankara'ya kaçtıktan sonra kaleme aldığı romanda 1909 senesinde tanıştığı “ev sahibi” İngilizlerden bahsetmez, ileride gazete yazılarında işgalci İngilizlerden bahsetmeyeceği gibi. Nitekim İngiltere'de ev sahibi olarak tanıdığı İngilizler, aynen Haswell ve Haswell'in sömürge ilişkilerinde gözlemlediği gibi, o bilindik sömürgeci tavırlarını takınıp, ev sahibi-misafir hukukunu altüst edip İstanbul'da ev sahipliği taslamaktadır. Ateşten Gömlek, bu “ev sahipliği” meselesini oldukça yakından irdeler. İstanbul'da bazı kibar sosyete hanımlar "ev sahipliğì” yaparak İngilizlerin sempatisini kazanmaya çalışırken, Ateşten Gömlek' in kahramanı Ayşe gibi diğer başka kadınlar ve erkekler de ev sahibi-misafir ilişkisinin işgal ortamında manasızlaştığını, milletlerin ancak barış ortamında böyle bir ilişkiye girebileceğini dile getirirler.

Ateşten Gömlek'in ilk sahnelerinden birinde İngilizler Harbiye Nezareti'ni bombalamaktadır. Romanın kahramanı Ayşe, ki bu kahramanın Halide Edib’i temsil ettiğini söylemek herhalde çok yanlış olmaz, İzmir'in işgalinden sonra İstanbul'a ulaşmış, eşini ve çocuğunu kaybetmiş bir kadındır. Erkek anlatıcı Peyami elbette çektiği tüm acılarla Anadolu'yu temsil eden Ayşe'ye âşık olur. Beraber Sultanahmet Mitingine giderler. Halide Edib miting hakkında çok fazla bilgi vermez, kendi adını geçirmez. Fakat Peyami mitingden döndükten sonra “"Milletler dostumuz, hükümetler düşmanımız’ olmuştu” (Adıvar, 1997 [1922], 31) der. Bu slogan Halide Edib'in 15 Mayıs 1919 tarihli Sultanahmet Mitingindeki konuşmacı platformu üzerinde yazan cümleyle aynıdır.

Anlatıcı daha sonra İngilizlere iyi görünmeye çalışan "salon" ev sahibelerinden birinin Ayşe'yi kendi tarafına çekmeye çalıştığı bir suareyi anlatır. Peyami’yi salonda en fazla rahatsı eden İngiliz gazeteci Mister Cook’tur:

Hâlâ tepemden akan ıstırap ve isyanla hatırlıyorum. Odada yalnız o varmış gibi oturuyor, iskelet gibi uzun bacakları diz kemikleriyle pantolonunun altından teressüm ediyor, kocaman ince ayaklarını mütemadiyen sallıyordu. Seyrek saçlı kafası, tüyü dökülmüş ihtiyar bir av kuşu gibiydi. Burnu kocaman, mütecaviz ve havada bulanık küçük gözleri birbirine yakın mavi iki boncuk gibi hissiz hissiz bakıyordu [...] Mütekebbir, kendi ile dolu, müstehzi, zaferi başına sıçramış, daima kendi kini için 'yerli' tabir ettiği müstemleke halkını çizmesinin altında ezen İngiliz İmparatorluğu'nun müstemleke zalimlerinin en cahil ve en aşağı bir enmuzeci. (Adıvar, 1997 [1922], 35-36)

Görünen o ki Mister Cook, Halide Edib'in 1909 senesinde İngiltere'ye giderken gemide karşılaştığ1 ve hiç hoşlanmadığ 1 Anglo-Hintlerden esinlenerek tasvir ettiği bir karakterdir. (Yazarın ilk mürebbiyesinin de bir Anglohintli olduğunu hatırlamakta fayda var.) Misafir olması gereken İngiliz, oturuşu ve bakışıyla ev sahipliğine soyunmuştur. Yırtıcı kuş bakışlarıyla Mister Cook, misafirperverliği sömürge ilişkileri kapsamında değerlendiren 
Haswell ve Haswell'in deyimiyle (Haswell ve Haswell, 2010, 21) salondakileri "yiyip yutmaya" hazırdır. Anlatıcı Peyami, Cook'un tavırlarından çok rahatsız olur. İttihat ve Terakki karşıtı olan evin sahibesini “Ali Kemal Bey'in makalelerini yaşayan Salime Hanım” (Adıvar, 1997 [1922], s. 21) olarak tanıtır. Nitekim Salime Hanım 1srarla Cook’a Türk milletinin İttihat ve Terakki'den çok çektiğini anlatıp durur. İstanbul artık İngilizlerle arkadaş olmak istemektedir. Peyami, Cook'un Salime Hanım'ın bu serzenişlerine kötü Fransızcasıyla şöyle cevap verdiğini söyler:

Evet, İngiliz himayesini baştan başlayarak hepiniz istemelisiniz. Bakın Hindistan'a, ne mesut. Allah bizi beyaz adamdan ayırmasın diye hep dua ederler. Gerçi bu zor işi İngiltere kabul eder mi bilmem, fakat sizin için başka türlü kurtuluş var mı? Bilhassa Çanakkale'de katlettiğiniz altmış bin İngiliz var. Samimi bir nedamet olursa belki İngiltere affedebilir. (Adıvar, 1997 [1922], 38)

Halide Edib burada gazeteci Mister Cook'u Türkiye ve Hindistan'1 “okurken” aynı yöntemi kullanmaya çalışan bir İngiliz olarak betimler. Ülkeler ve metinler Haswell ve Haswell'in kavramsallaştırmasında olduğu gibi yer değiştirmiş, ev sahibi-yazar ve okurmisafir ikilileri misafirin metni işgal edip ev sahibiymiş gibi kontrolü ele geçirmesiyle ters yüz olmuştur (Haswell ve Haswell, 2010, 22) Bu makalede de tam bu sebepten dolayı Halide Edib'in bir Türk olarak İngiltere'yi anlama çabası sömürge ilişkileri kavramları üzerinden değerlendirilmektedir. Cook'un, Halide Edib'in 1909 yılında Londra'da beraber vakit geçirdiği, ona ev sahipliği yapan ve 1939 yılında resmedeceği, kendi ülkelerinde yaşayan İngilizlerle alakası yoktur. Cook’un yukarıdaki sözlerine öfkelenen Ayşe, Cook’a cevaben İngilizlerin Yunanlıları İzmir'i işgal etmeye kışkırtarak çok yanlış hareket ettiklerini, Cook'unkinden çok daha iyi bir Fransızcayla dile getirir. Özür dilemesi gerekenler İngilizlerdir. Kolonyal memur karakteri Cook, Halide Edib'e sömürgeci söylemini ifşa etme olanağı tanır. Kahramanımız Ayşe de bu sömürgeci söylemin nasıl eleştirilmesi gerektiğini bize gösterir. İngilizlerin İstanbul'daki evlere el koyması da yine Haswell ve Haswell'in bahsettiği ev sahibi - misafir - işgalci kategorilerinin yer değiştirmesine iyi bir örnektir. Ayşe kendi evine de el koyulunca tam olarak nereden çıktığı belli olmayan bir şekilde, sanki kendi şahit olmuş gibi Hindistan'da geçen bir olaydan bahseder:

Allah'ım! İngiliz kadınına hakaret etti diye [bir] Hintliyi İngilizler dört ayak hayvan gibi yerde yürütmüşlerdi. Türk kadınının azametini çekemeyenlere, yerde sürdürenlere karşı ordumuz aynı ihtirasla ceza istemeyecek mi? Kadınına hakareti, bayrağına hakaret gibi düşünmüyor mu? (Adıvar, 1997 [1922], 59)

Bu pasaj Halide Edib'in sömürge karşıtı tavrını yansıtmakla birlikte aynı zamanda savaş dönemlerinde kadın bedenlerinin nasıl vatanın birer sembolü haline geldiğinin kanıtlarından biridir. Hindistan ve Türkiye'nin İngiltere karşısındaki direnişinin iki ülkeyi birbirine bağlıyor olmasından Halide Edib daha sonra Hindistan seyahati hakkında yazdığı Inside India'nın önsözünde de bahseder. 1937 yılında Londra'da İngilizce olarak yayımlanan 
kitapta Halide Edib'in Hindistan algısının İngiltere'yle olan ilişkisiyle ilintili olduğu açıktır. Kitabın önsözünde Hindistan'ın Halide Edib için çok özel bir yeri olduğunu öğreniriz. Yazar kendini Türkiye'den sonra ancak Hindistan üzerine yazmakta ehil görür:

Evladı olmadığım bir ülke hakkında kişisel intibalarım dışında hiçbir şey yazmamak şiarım olmuştur -ki bu intibaları da çok nadir paylaşırım. Bu kuralı küçüklüğümden beri tanıdığım, dört seneden fazla ikamet etmekte olduğum, çeşitli dönemlerde ziyaret ettiğim İngiltere için bile bozmadım. Ama yine bu kuralı Inside India'yı yazarak bozuyorum. (Halide Edib, 1937, 9)

Halide Edib bu kuralını istek üzerine bir kere daha, 1939 yılında "İngiltere ve İngilizler" adlı bir dizi gazete yazısı yazarak bozacaktır. Yazar Inside India'da Hindistan ve Türkiye arasındaki benzerliklerden, bu benzerliklerden dolayı çok sıcak karşılandığından ve yine bu benzerliklerden dolayı Türkiye'nin ulusal direniş için bir model oluşturduğundan bahseder. Hindistan ve İngiltere arasındaki ilişki Halide Edib'in kendi ev sahibi, işgalci, misafir algılarını iyice oturtmasına yardımcı olur. Öyle ki, Halide Edib'in Hindistan ile ilgili ilk izlenimleri İngilizlerin sömürgeci kimliklerine dair ilk izlenimleriyle iç içe geçmiştir. Halide Edib iki ülkeyi hep bir arada düşünecektir:

Daha sonra hayatıma 40 sene öncesinin Hindistan'ını anlatan İngiliz mürebbiye girdi. İngiliz bir çay üreticisinin eşi olarak ülkede 30 sene yaşamıştı [...] Hindistan imparatorluk hayalleri güden bir ırkın arka bahçesi olmuştu. Ülkeyi Olympus dağındaki tanrılar gibi yönetiyorlardı. Filleri sürdüler, kaplanları ve ormandaki tüm vahşi hayvanları avladılar. İçlerinde en mütevazı olanı bile gölgesiyle kudretli Cengiz Han gibi manzaranın tümünü kapladı [...] Mürebbiyeme göre beyaz adamların fevkalade sağlam karakterleri vardı. (Halide Edib, 1937, 13-14)

$\mathrm{Bu}$ giriş Halide Edib'in daha çok küçük yaşta sömürge söylemiyle tanışmış olduğunu gösteriyor. Yazarın ilk Hindistan bilgileri bir İngiliz'in merceğinden geçmiş bilgilerdir. Fakat 1937 yılında yazan Halide’nin mürebbiyesinin sözlerini istihza ile aktardığı açıktır. 1939'a gelindiğinde $A$ kşam gazetesindeki İngiltere yazılarında bu ince alayı yakalamak biraz daha zordur.

\section{Ingiltere'de Misafir Olmak}

Ateşten Gömlek'ten, Anadolu'da savaştıktan, Ankara'da yeni bir başkentin kurulmasına tanıklık ettikten sonra Halide Edib 1926 yılında eşi Adnan Adıvar'la tedavi için Viyana'dayken Türkiye'ye geri dönemeyeceklerinin haberini alırlar. Adnan Adıvar Terakkiperver Cumhuriyet Fırkası vekilidir ve Halide Edib ve Adnan Adıvar Viyana'dayken sıkı yönetim ilan edilince muhalefet partisinin vekillerinin özgürlükleri de tehlike altına girer. Çift, tıp doktoru olan Adnan Adıvar'ın İngilizce bilmemesine rağmen ortalık yatışıncaya kadar Londra'da yaşamaya karar verir. Muhtemelen İngiltere'yi Halide Edib'in edebî hayatına daha kolay devam edebilmesi için seçmişlerdir. Yazarın 1920’lerde işgalci olarak tanıdığı 
İngilizler şimdi onlara ev sahipliği yapacaktır. Haswell ve Haswell'in bahsettiği ev sahibiyazar, misafir-okur arasındaki hassas güç ilişkisi açısından değerlendirildiğinde Halide Edib ve İngiltere arasındaki ilişki kompleks bir katman daha kazanmış, tekrar bir değişime girmiş olur.

Halide Edib ve Adnan Adıvar ilk önce Chiltern Hills'de Halide'nin 1909'da ziyaret etmiş olduğu eğitimci Isobel Fry’ın okulunun karşısında bir ev tutarlar. Halide Edib ilk daktilosunu da bu dönemde alır ve daha sonra 1963'te Türkçede Mor Salkımlı Ev olarak yayımlayacağı, 1918 yılına kadar olan hatıratı Memoirs of Halide Edib'i yazmaya başlar. Halide Edib İngiltere'de kaldığı dönemde Arnold Toynbee ve Bertrand Russell da dahil olmak üzere entelektüel dünyadan isimlerle bir araya gelme firsatı bulur. Chilterns'daki evde yaşarken Fry'ın evindeki akşam okumalarına katılır. Chilterns' dan sonra günümüzde merkezî sayılabilecek bir Londra mahallesi olan Hampstead'e taşınır. Bu tecrübelerine rağmen Halide Edib Inside India'nın önsözünde belirttiği gibi evladı olmadığı İngiltere hakkında bir şey yazmaz. Daha doğrusu o seneler bir şey yayımlamaz. Bu Halide Edib’in okur-yazar arasındaki misafirperverlik kurallarını uygulama tarzı olarak düşünülebilir.

Çalışlar, Halide Edib'in bu dönemde yazdığı bazı mektuplara ulaşmıştır ve bu mektuplar yazarın İngiltere ve İngilizlerle olan ilişkisinin "Bilgi Cumhuriyeti” çerçevesinde geliştiğini göstermektedir. Örneğin, tanıştığı insanlar hakkındaki izlenimleri bu insanların hangi yazarlardan hoşlandıkları, demokrasi ve sosyalizm gibi ideolojiler hakkında neler düşündükleri doğrultusunda şekillenir. Bu "Bilgi Cumhuriyeti”nde milli rekabetin bir yeri yok gibidir. Çalışlar'ın alıntıladığı mektuplardan anlayabileceğimiz üzere, Halide Edib'in Hampstead'deki evde mutlu olmasının sebeplerinden biri, ev sahibesinin salondaki kitaplığ kilitlemeyip, ortak kullanıma izin vermesidir (Çalışlar, 2010, 320). İngilizlerin ev sahipliği Halide Edib için edebî bir çerçeveye kavuşur. Halide Edib'in Hampstead'deki bu evde kendini kendi evinde gibi hissetmiş olduğunu Amerikalı arkadaşı Florence Billings'e yazdı̆̆ mektupta onu Londra'ya davet etmesinden anlıyoruz. Billings de o zamanlar "Yakın Doğu Sorunu" üzerine çalışmaktadır ve Halide Edib, Billings'in gelip onlarda kalıp Londra'daki kütüphaneler ve kaynakları kullanabileceğini söyler:

Yakın Doğu sorunu üzerine çalıştığınıza göre, buraya gelmek için neden ilkbahara kadar bekleyeceksiniz? Burada da çok zengin malzemeler bulursunuz ve ayrıca sizin için her şeyi yapmaya hazır olan bizler varız. Hampstead bölgesinde, yarı bodrum bir dairede oturuyorum. Arkadaki odaların muhteşem bir manzarası var, bir göl var, ağaçlar var, güneşin batışında ağaçların arkasında minareye benzeyen kuleler var ve kraliçenin kuğuları geceleri onun karanlık gölgelerinde çok sevimli daireler çiziyor. Bizimle yaşamak isterseniz, sizin için bir yatak odasına dönüştürebileceğim göle bakan küçük bir ek odam bile var. Ya da size bize yakın çok rahat bir oda bulabilirim ve bütün yemekleri bizimle yiyebilirsiniz. Böylece fazla pahalı olmaz. (Çalışlar, 2010, 331) 
Mektuptan anlaşılacağı üzere Halide Edib bir manada misafir olduğu evde ev sahipliği yapmaya hazırlanmaktadır. Hatta gururlu bir ev sahibi gibi zevkle evini ve manzarasını anlatmakta, herhangi bir hüzün ibaresi kullanmadan Londra'nın mimarisini İstanbul mimarisine benzetebilmektedir. Halide Edib bir manada Haswell ve Haswell'in tasvir ettiği ev sahibi-yazar, misafir-okur kategorilerini aşıp, daha simbiyotik bir yaklaşımın sinyalini vermektedir. Haswell ve Haswell misafir - işgalci - ev sahibi rollerinin değişimini daha çok siyasi ve söylemsel şiddet çerçevesinde değerlendirirken burada daha yumuşak bir geçiş var gibidir. Misafirlikten ev sahipliğine geçiş, özellikle sürgün söz konusu olduğunda, yerel yaşayış biçimine galip gelmekten çok yerel yaşayış biçimlerine teslim olmak olarak da değerlendirilebilir. Halide Edib' in bu dönemde yazdığı mektuplarda hasret hissi pek görülmez. Yazar Ankara'nın belli bir dönemden geçtiğine ve bunun önünde sonunda biteceğine inanır gibidir. Yine de bazen kendi özlemini eşi üzerinden ifade ettiğini söylemek mümkündür. Adnan Adıvar'ın vatan hasretini, yine Billings'e şöyle anlatır: "Diyebilirim ki, vaktiyle vücutları ateşe verilen ve 'parlamento çetesi' denilenlerin yandığı bu yerde, Adnan'ın ruhu da yanıyordu." (Çalışlar, 2010, 330) Hampstead siyasi sürgünleri kendine çeken bir mahalle gibidir. Adıvarlar kendilerinden önce burada yaşamış siyasi yasaklı kişilerin hatırasından güç alırlar. Aynı zamanda Hampstead Heath'de de Hyde Park'takilere benzer konuşmacılar vardır ve bunlar Halide Edib'i derinden etkiler. Londra, Halide Edib'e bu muhaliflerin hatırası ile ev sahipliği eder, kendi muhalifliği hakkında düşünme fırsatı verir. Çalışlar (2010) Adıvarların Londra' daki yaşamını anlatırken arkadaşlarının biyografilerine de başvurup, Rauf Orbay'dan şöyle bir anı alıntılar:

[H]epimiz bilhassa Dünya Harbi ve İstiklal Mücadelesi yıllarında ferdi sıkıntıların her çeşidini tatmış, adeta bunlarla yoğrulmuş insanlardık. Fedakarlığı, hatta günde bir öğün yemeği yadırgayacak tarafımız yoktu. Şükür ki hiçbirimizde sigara alkolün her çeşidi ile kılık kıyafet moda iptilaları yoktu. Kendilerinin bir buçuk oda evlerini tedirgin etmemek için bir köşe kıyıda pek mütevazı ama büyüklü küçüklü İngiliz otel pansiyonlarının vazgeçilmez tarafı temizliği bulunan bir çatı odası buldum. Boş zamanlarımızı Hyde Park’ta konserleri dinleyerek geçiriyorduk. (339)

Halide Edib, iktisatlı davranması gereken bu dönemde yine de sosyalleşmekten geri kalmaz. Bertrand Russell'la görüşür ve Londra entelektüel çevrelerinin sürekli Rus devriminden bahsettiklerini görür. Halide Edib'in 1939 gazete yazılarından anladığımıza göre İngiltere' de kişisel özgürlüklerin çok büyük öneme sahip olması yazarı çok etkilemiştir. Manchester Guardian muhabiri olarak Türkiye'de olduğu dönemde tanıştı̆̆ 1 Arnold Toynbee de Halide Edib'in Londra'da görüştüğü yazarlardandır. Toynbee'nin Acquaintances (1967), adlı kitabının "Bazı Türk Arkadaşlar” bölümünde yazar hem Türkiye’yle olan karmaşık ilişkisinden bahseder, hem de Halide Edib, Adnan Adıvar ve Rauf Orbay'ın portrelerini çizer. Toynbee de bir zamanlar İngilizlere karşı savaşmış olan Halide Edib ve Adnan Adıvar'ın Londra'daki ironik durumunun farkındadır: 
Adnan ve Halide vatanseverliklerinin bedelini sürgüne gitmek zorunda kalarak ödediler -onları kovan da memleketin düşmanları değildi üstelik [...] Milli kriz atlatıldıktan sonra, vatanı Adıvarlar gibi kendi çıkarlarını düşünmeden milli mücadeleye katılan silah arkadaşlarıyla kazanan ulusal lider tarafından sürgüne mecbur edilmişlerdi. Atatürk'ün ölmesiyle ülkelerine geri dönen Adıvarlar ilim olan doğal mesleklerine kaldığı yerden devam ettiler. Halide zaten bir romancı olarak ismini duyurmuştu, şimdi de İstanbul Üniversitesi'nde İngiliz Edebiyatı profesörü oldu. Adnan ise Íslam Ansiklopedisi'nin Türkçe versiyonu olacak bir projenin başına geçti. (232)

Halide Edib Londra'da neden orada olduğunun sebeplerini anlayan birçok arkadaş bulur: Bu durum yazara siyasi ve kültürel anlamda Atatürk'le ters düştüğü noktalarda haklı olduğunu hissettirmiş olmalı. Nitekim 1939 yılında yazacağı gazete yazılarında da İngiltere entelijansiyasının çalışma şekli ve siyasete getirdiği eleştiriler önemli yer tutar. Halide Edib’in İngiltere'deyken sık sık röportaj verdiğini görüyoruz. Bu yazının başındaki röportaj da dahil olmak üzere Halide Edib basına verdiği demeçlerde Ankara hükûmeti ve Atatürk aleyhine çok bir şey söylemez. Atatürk'ün bazı despotik eğilimleri olduğunu kabul etmekle beraber, bu gibi söyleşileri mutlaka Atatürk'ün ülke için, kadın hakları için çok önemli şeyler yaptığını söyleyerek bitirir.

\section{Bugünün Ev Sahibi, Dünün Düşmanı}

Halide Edib Londra'daki "Bilgi Cumhuriyeti”nde bir çok dost edindiği dönemde, yine kaderin bir cilvesi olarak, İstanbul'u işgal eden İngilizleri betimlediği bir metin üzerinde çalışır. Misafir olarak İngiltere'de bulunan Halide Edib'in işgalci olarak tasvir ettiği İngilizler misafir - ev sahibi hukukunu İstanbul'da ihlal etmiştir. Haswell ve Haswell'in vurguladığı gibi sömürge ve işgal durumu ev sahipliği ve misafirperverlik kurallarını yıkar. Yazar bu dönemde Türk'ün Ateşle Imtihanı'nın belki de en uygun çevirisi olarak The Turkish Ordeal isminde bir savaş anıları metni kaleme alır. Ateşten Gömlek'te kurgu bir metin içerisinde tasvir ettiği İstanbul işgalini ve Milli Mücadele'yi bu sefer anı olarak yazıya geçirmesinin bir sebebi de Mustafa Kemal Atatürk'ün 1927'de Cumhuriyet Halk Fırkası kongresinde verdiği, altı gün süren bir demeç olan Nutuk'tur. Hülya Adak "National myths and self-na(rra)tions: Mustafa Kemal's Nutuk and Halide Edib's memoirs and The Turkish Ordeal" makalesinde Nutuk'un metninde Adnan Adivar'ın bir üyesi olduğu Terakkiperver Cumhuriyet Fırkası'nın kapatılmasının sebeplerinin açıklandığına $(2003,510)$ dikkat çeker. Partinin kapatılması ve peşi sıra gelen siyasi havanın Adıvarların İngiltere'ye sürgüne gitmelerine sebebiyet verdiği düşünülürse, Halide Edib'in bu metne kendi metni ile karşılık vermesi doğaldır. Daha önemlisi Mustafa Kemal metinde Halide Edib'in Amerikan mandasını özgürlüğe tercih ettiğini iddia etmektedir (2003, 511). Durakbaşa Halide Edib ve başka bir takım vatansever aydınların o senelerde emperyalist güçlere karşı Amerika'dan yardım istemiş olduklarının bir vakıa olduğunu hatırlatır (2467). Çalışlar (2010) da Nutuk'un üslubunu şöyle tarif eder: 
Bugün Cumhuriyet tarihinin resmî belgesi olarak kabul gören Nutuk, hakaret içeren sıfatlarla söz ettiği muhalifleri değersiz kılmayı da hedefliyordu. Nutuk'ta, Halide Edib'in Mustafa Kemal Paşa'ya hitaben yazdığı, '...muvakkat [geçici] bir Amerikan mandasını, ehven-i şer olarak görüyoruz' diyen mektubu da yer alıyordu. Yazıldığı tarihte İstanbullu adayların ortak bir çözüm önerisi olarak görülen mektup, Halide’yi vuran bir silaha dönüşmüştü. (345)

Halide Edib böylelikle kendini birden fazla anlatı cephesinde savaşırken bulur. Hem İstanbul'daki İngiliz mezalimini, hem de Anadolu'da Atatürk'le yaşadığı fikir ayrılıklarını anlatacağı bir metin yazmaya koyulur. 1928 yılında Londra'da basılan The Turkish Ordeal İngiliz işgali sırasında İstanbul'daki havayı tarif ederek başlar:

Evlere el konulması, sakinlerin şahsi eşyalarını alamadan dışarı atılması - bunlar yapılan eziyetlerin en hafifleriydi. Müttefik polislerinin -özellikle İngilizlerinTürklere olan tavrını büyük ölçüde tuttukları Yunan ve Ermeni çevirmenler ve yardımcılar belirliyordu. (1)

Halide Edib, evlere el konulması meselesini yukarıda da bahsettiğim gibi Ateşten Gömlek'te de ele almış, savaş zamanında "ev sahibi” ve "misafir”'in nasıl yer değiştirdiğine dikkat çekmiştir. İngilizler İstanbul'da işgalin bir sonucu olarak sömürgelerdeki gibi ev sahipliğine soyunmuştur. Haswell ve Haswell' in de dediği gibi ev sahibinin evsiz bırakılması sömürge yönetiminin en önemli özelliklerinden biridir. Hem fiziksel, hem de söylemsel olarak evsiz bırakılan bir çok Türk gibi, Halide Edib de İstanbul'da "misafir" olmaktansa, hâlâ rahatlıkla ev sahipliği yapabileceği Anadolu'ya, Ankara’ya geçmeyi tercih eder. Halide Edib İngiltere'de İngilizlerle gayet iyi komşuluk yaptığ İngilizleri, kendi dillerinde, şöyle tasvir etmektedir:

Utanmış olduğumu itiraf etmeliyim. İngiliz makamlarla hiçbir şekilde görüşmeme kararı almıştım. Benden zehir gibi nefret ediyorlardı ama yine de sonunda kendimi Rumeli Hisarı'nda Colonel Heathcote Smythe'la görüşmeye ikna ettim [...] Colonel Heathcote Smythe'1 son görüşümden bu yana İngilizlerin Türklere karşı daha yumuşak ve insani bir tavır takınma ihtimalleri iyice imkânsızlaşmıştı. [...] İngiliz Karargâhı basbayağı Türkler ve Hıristiyanlar arasında şiddetli ve kanlı bir çatışma yaşanmasını istiyordu. Bu duyumlara göre elbette birbirimizin boğazına girmemiz onların işine gelecekti. Bunu bahane edip İstanbul'u işgallerini meşrulaştıracaktı. $(1928,14)$

Burada barış zamanında gelmiş olsalar hiç şüphesiz gayet iyi bir ev sahibi olarak karşılayacağı İngilizlerin Halide Edib'in ev sahipliği hakkını nasıl elinden aldıklarını görüyoruz. Yazar yine de İngilizler hakkındaki söylemini gayet soğukkanlı tutmaktadır. Adıvarlar İngilizlerin ertesi gün, 16 Mart 1920'de, Osmanlı meclisini kapatacaklarını öğrendiklerinde ne yapmaları gerektiğini tartışırlar. Adnan Adıvar İngiliz askerleri geldiğinde mecliste olmak istemektedir, Halide Edib ise görevlerinin tutuklanmayıp Ankara'ya geçmek ve Mustafa Kemal'e katılmak olduğunu 
söyler. Adnan Adıvar, yukarıda Ateşten Gömlek'te gördüğümüz, Halide Edib'in Sultanahmet Mitingindeki sloganını hatırlatıp onu ikna etmeye çalışır:

“Milletler dostumuz, hükümetler düşmanımız’ diyen sen değil miydin? Milletlerin, İngiliz milletinin, kendi hükümetlerinin, en eski parlamenter sistemin, başka bir parlamentoya sayg1 göstermediğini gösterelim.’ Bunu duyunca gözümün önüne Roma yabancılar tarafından alınırken koltuklarına sıkı sıkı oturmuş yaşlı Romalı senatörlerin olduğu bir sahne geldi. (Halide Edib, 1928, 15)

Aralarında geçen konuşmayı bilmek mümkün değil, ama Halide Edib burada Adnan Adıvar'ı kendi içinde yaşadığı tartışmayı yansıtmak için bir figür olarak kullanır gibidir. Nitekim Halide Edib İngiliz parlamentosu hakkındaki buna benzer düşüncelerini 1939 yılındaki "Parlamentolar Anası" başlıklı gazete yazılarında anlatacaktır. İngiliz işgalcilerin kendilerine karşı takındıkları tavra rağmen Halide Edib ve Adnan Adıvar hâlâ İngiliz ve Osmanlı halklarının birbirlerini anlayabileceği inancını yitirmemiştir. İngiliz ordusu İstanbul'daki yaşam tarzını tehdit ederken Halide Edib, belki de bir güç simgesi olarak söylemsel misafirperverliği tamamıyla elden bırakmamak için, gördüğü İngiliz erlerine karşı hâlâ anlayışla bakabilmektedir. Ankara’ya kaçarken kendilerinden saklandığı İngiliz askerlerini şöyle tarif eder:

Bir İngiliz askeri büyük bir ağacın altında ayakta durmuş, yorgun bir çehreyle yolu gözetliyordu, arkasındaki bir yükseltide üç tanesi daha vardı. Bir ayna telgrafiyla sinyal yolluyorlardı. Başımı arabadan uzatıp onları ilgiyle incelemeye koyuldum. Özellikle yolu gözetleyen adama acıdım. Ne kadar soluk, sarı ve mutsuz görünüyordu - sıtmalı olmalıydı. Ona karşı bir nefret ya da intikam duygusu hissetmedim. Ben avlanan bir tilki olarak kurban rolünde isem, onlar da işlerinden zevk almayan zorbalardı. Nasıl da evinde olmayı istemiş olmalı! (Halide Edib, 1928, 61)

Halide Edib'in buradaki söylemi bir bakıma yazarın Türkiye'deyken İngilizlerle olan münasebetinin asli rengine dönüşüne işaret eder. Yazar tilki değil ev sahibi, İngilizler zorba değil misafir olmalıdır. İngiliz askerlerin insani duygularını ve onları gören Türk kadınındaki şefkat uyanmasını Ateşten Gömlek'te görmek elbette mümkün değildir. Roman İngiliz işgali döneminde yazılmışken, yukarıda alıntıladığım The Turkish Ordeal pasajı İngiltere'de, savaştan en az 10 sene sonra yazılmıştır. Halide Edib'in Hampstead'de İngilizler hakkında yazdıklarının orada ona ev sahipliği yapan entelektüellerin gösterdiği ilgi çerçevesinde dönüşmüş olduğunu düşünmek yanlış olmaz. Yine de burada anlayış gösterilen İngilizler basit askerler, Ateşten Gömlek'te yerilen İngiliz karakter ise İngiliz propaganda makinesinin erlerinden biri olan gazeteci Mister Cook'tur. Halide Edib Ateşten Gömlek'te her ne kadar İstanbul'un derdini İngilizlere anlatmaya çalışan kadınları eleştirse de kendisi de The Turkish Ordeal ile benzeri bir şey yapmaktadır. İngilizlerin dilinde yazdığ 1 kitaplar ve verdiği röportajlarla İngilizce konuşan kitlelere Türklerin imtihanını ve yeni giriştikleri cumhuriyet projesini anlatır. 


\section{İngilizleri Tercüme}

İngiltere'de yerleşmişken Amerika ve Hindistan'da dersler verip daha sonra Paris’te bir müddet kalan Halide Edib sonunda 1939 y1lında, Atatürk'ün ölümünün ardından Türkiye'ye geri döner. 1939'da İtalya'nın Arnavutluk'u işgal etmesinden sonra İngiltere ve Türkiye arasında bir savunma anlaşması imzalanır. Bunun hemen ardından da Akşam gazetesi Halide Edib'in eski işgalci bu yeni "müttefik" hakkında bir dizi yazı yazmasını ister. Gazete yazı dizisini şöyle lanse eder:

Dostlarımız olan İngilizleri iyi tanımayız. Halkımız onları garip ve anlaşılmaz âdet ve ananelere bağlı telakki eder. Türk efkârı umumiyesine mesela Fransızlar ve Almanlar gayet iyi izah edildiği halde, İngilizler layıkiyle anlatılmamıştır.

Halbuki mukadderatını birbirine bağlayan bu iki asil milletin iyice tanışması lazımdır.

İngiltereyi, İngilizleri ve İngilizleri İngiliz gibi bilen büyük Türk edibi Halide Edib Akşam gazetesinde İngiltere ve İngilizleri anlatan bir yazı silsilesini neşredecektir. İlk yazı: Manş denizini geçerken Cumartesi nüshamızda (Akşam, 9 Haziran 1939, 7)

Halide Edib bu övgüye Inside India kitabının girişine benzer bir şekilde hiçbir ülkeyi Türkiye gibi bilemeyeceğini söyleyerek cevap verir. Fakat yine de, yazarın da dediği gibi, dışarıdan bir gözlemci olmanın avantajları vardır. İngilizlerin neyimiz, ne kadar dostumuz olduğu konusunda da Akşam gazetesinin editörüne nazaran biraz daha ihtiyatlıdır:

Sulh ve insaniyeti korumak yükünü beraber taşımayı taahhüd ettiğimiz İngilizlerle omuzdaş mıyız, yoldaş mıyız neyiz bilemiyorum, fakat mutlak onları bilmemiz lazım geldiğine inanıyorum. Onun için İngilizler ve İngiltere hakkında bildiklerimi vatandaşlarımla paylaşmak istiyorum. Bunun hakkında Akşama vereceğim makale serisi programl, mürettep bir eserden ziyade teklifsiz uzun bir konuşmadan ibarettir. Küçük bir 1stıtrad yapayım:

'Akşam' bu seriyi ilan ederken muharriri İngilizleri bir İngiliz kadar bilir diye tavsif ediyor. Bence hiçbir ecnebi herhangi bir milletin dil, hars ve memleketini ne kadar bilirse bilsin o memleketin evladı şeklinde bilemez. (Halide Edib, 9 Haziran 1939, 7)

Bu girişten sonra Halide Edib “İngiltere ve İngilizler” başlığı altında 15 yazı kaleme alır. $\mathrm{Bu}$ yazı dizisi İngiltere söz konusu olduğunda yazarın okur-misafir olarak başlayan konumunun bir bakıma Türk okurlarını ağırlayan ev sahibi-yazar olarak değişmesi manasına gelecektir. Yazarın da biraz kinayeyle belirttiği gibi Türkiye-İngiltere ilişkileri hakkında kesin bir yorum yapmak zordur. Konu Halide Edib - İngiltere ilişkilerine gelince mesele daha da karmaşıklaşır ve yazarın "neyiz bilemiyorum"u biraz daha derinlik kazanır. Halide Edib bu yazılarda parlamenter sistem, siyasi partilerin iç işleyişi, süfrajetler, Viktoryen dönem, İngilizlerin radikalizm ve devrim karşıtlı̆̆ 1 , eğitim sisteminin sınıfları nasıl birbirinden ayırdığı ve ülkenin bir anayasasının olmayışından bahseder. Halide Edib’e göre bir memleketin parlamenter sisteminin nasıl şekil almış olduğu, o milletin ruhunu yansitır. 
Yazıların çoğu gazeteci dilinde, sohbet şeklinde yazılmış olsa da Halide Edib'in İngiliz siyasi sistemini gayet derinden kavradığı görülmektedir. "Parlamentolar Anası" adlı yazısında İngiltere meclisinin nasıl bir model olduğunu ayrıntısıyla şöyle anlatır:

İngiliz parlamentosuna bu lakab, kısmen eski olduğu için, kısmen de esaslarının dünya parlamentolarına yaptığ 1 derin tesirden dolayı verilmiştir. Esasen ilk manası (konuşmak) olan parlamento kelimesi her hangi milletin lisanına yerleştiği gün idare edenlerle edilenler arasında hiç olmazsa istişari bir münasebet mefhumu başladığını gösterir. Maamafih parlamento esasları ve teşekkülleri, bu kelime ile İngiliz lisanına girmeden çok evvel, İngiltere'de yerleşmiş bulunuyordu. Kelimenin kendisi (model) ünvanı verilen 1295 parlamentosile resmiyet kesbetti. (Halide Edib, 26 Temmuz 1939, 7)

Yazarın burada kullandığı dili nazar-1 dikkate aldığımızda Türkiye'nin ilk meclisinin kurulma aşamalarına şahitlik etmiş olan Halide Edib'in Ankara'daki siyasi katkılarının İngiliz modeli hakkındaki bilgisiyle şekillenmiş olduğunu söyleyebiliriz. Görünen o ki yazar Londra'da geçirdiği dönemde İstanbul'un işgalini ve Ankara mücadelesini kaleme almakla beraber, etrafını da yakından incelemiş ve İngiltere hakkında önemli gözlemler yapmıştır. Halide Edib'in bu gözlemleri kültür, siyaset ve eğitim alanında İngiltere'deki iyi örnekleri Türk halkına uygulanması mümkün birer seçenek olarak sunmaya yönelik gibidir. İngiltere'yi bir metin gibi okuma sırası Halide Edib'e gelmiştir. Haswell ve Haswell'in anlatımında bir ülkenin metin gibi okunması sömürgeciler tarafından yapıldığında yerel halk yenip yutulur. Burada ise işgal edilmiş olanın işgal edeni okuması sonucu gerçekleşen "yiyip yutma" birtakım kurumların işleyişini öğrenme ve bu kurumların işgalden yeni kurtulmuş bir halk için nasıl inşa edilebileceğinin ön çalışması mahiyetindedir.

Tanzimat'tan beri Türk halkını meşgul eden başka bir mevzu da elbette aydınların durumudur. Halide Edib bunun için de bir örnek seçer. Gazete için yazdığ 1 beşinci yazı “İnsan ve Zihniyet Portresi”nde uzun uzun Henry Nevinson adlı bir entelektüelden bahseder. Halide Edib için Nevinson sistemin içinde kalarak ülkenin fikri hayatına katkıda bulunan aydının en iyi örneğidir.

Yalnız bazılarında hatta muhitin tazyikine rağmen zulme isyan hassası daha kuvvetlidir. Nevinson herhalde bu tiplerdendir. Onun İngiliz olan tarafi bu insiyakı bir ideolojiye derhal raptedip o gün henüz çekirdek halinde olan Amele partisine iltihak etmemesi idi. Esasen, gene herhangi İngiliz gibi ferdin herhangi sahada fikrini söylemek hakkını kullanıyordu. Ve gene bütün meselenin İngiliz tarafı İngilterede Nevinson gibi düşünen, söyliyen, fikir sahasında mücadele eden birçok adam olduğu halde İngiltere içtimai tekamülünü ihtilalsiz yapıyordu. Çünkü -ister rahatını bozmamak istediğine atfedin, ister muhafazakarlığına- İngiliz müfrit (Radicalisme) den hoşlanmaz. Aubray Herbert isminde vaktile Türklere çok düşman, harbin sonlarına doğru çok kuvvetle Türk taraftarı olan bir İngiliz mebus 
ve muharriri 'Ben kendim' ismindeki kitabında, İngilizlerin genç Türk ihtilaline karşı gösterdikleri katılık hatta düşmanlığın amilleri arasında (Radicalisme)e karşı insiyaki ihtirazlarını da zikrediyor. (Halide Edib, 27 Haziran 1939, 7)

Halide Edib Nevinson'da İngiliz aydının alâmetifarikasını bireyselcilik olarak tespit eder. Yazar Nevinson örneğinden yola çıkarak serbest ve meşru bir şekilde girişilen fikir çatışmasının kurumları zedeleyen değil güçlendiren bir şey olduğunu söyler. İngiliz tarz-1 siyasetini, Türkiye Cumhuriyeti projesinin İttihat ve Terakki'den beri 1930'larda hâlâ bir parçası olan radikalizmi eleştirmek için bir araç olarak kullanır. Söylemsel çerçevede "yiyip yutma" sırası bu sefer evi işgal edilen Halide Edib'e gelmiştir. İngiltere'nin, işgalcinin, kendi evinde, yani İngiltere'de kullandığı bazı yöntemler, işgal edilenin bazı kurumları yeniden kurabilmesi için kullanılabilir.

Halide Edib Türk okurlar için İngilizliği tanımlamaya çalışırken mercek altına aldığ1 İngilizlerin milletlerinin temsilcisi olmayı reddedebileceğinin de farkındadır. Hatta İngilizlerdeki "bireyselcilik" güdüsü o kadar güçlüdür ki, bu aydınların bazıları İngiltere’yle ilişkilendirilmek bile istemezler. İşte tam da bu tavır İngiliz aydını tavrıdır. Ve bu tavır "İnsan ve Zihniyet Portresi” adlı Akşam gazetesi yazısında da belirttiği gibi Halide Edib'in gözlemlediği İngiliz tavırlarının arasında, Türkiye’de Fransa’yı model olarak alan pek çok aydın olmasına rağmen Türkiye'ye en yabancı, en ithal edilemezi olsa gerektir:

Yemekten sonra gelen misafir bambaşka bir tipti: Ressam ve sanat münekkidi Roger Fry. Ev sahibimin kardeşi olduğu için resimlerini odanın duvarından görmüştüm. [...] Yanakları çökük, yüzü uzun, siyah ve parlak gözleri çukur, kaşları kalın ve siyah, alnı çıkık, esmer, zayıf bir adamdı. İhmalkar ve soğuk renkli olduğu kadar şahsiyet ve zevk ifade eden giyinişinin tarzını değiştirirseniz tip olarak pekala bizim şark vilayetlerinden bir ferd olabilirdi [...] R. Fry yalnız Victoria devrine aid değil, herşeyde İngiliz olan şeylere karşı en çok itiraz eden İngiliz mütefekkiri örneğinin çok bariz bir nümunesiydi. İngiltereden ziyade Fransayı sevdiği anlaşılıyordu. Bunda çok samimi idi. Hayatının sonuna kadar Fransız köylerinde, kıyılarında en çok dolaşmış bir adamdı. Fransızların yalnız mütefekkir değil, halk örneğini de çok dikkate şayan buluyordu. Bunu ben onun çok İngiliz olduğuna atfediyorum, çünkü Fransızın pek bariz bir şekilde mantığa, kafaya, vuzuha istinad eden düşüncesi, zevki ve hayatı İngilizin daha çok insiyaki; kanaatleri muhakemeden fazla dürüst ve realist görüşleri daha çok fitridir. (Halide Edib, İnsan ve Zihniyet Portresi, 1939, 7)

Türkiye'de Fransa'yı Türkiye'den daha çok seven, daha çok beğenen aydınlar elbette vardır, ama hiçbiri bunu kamusal bir kimlik olarak benimseyemez. Bu yazıları 'Türkleştirme' uğraşı devam eden Türkiye'de yazan Halide Edib, okurlara İngilizlerin medeniyet kavramını anlatmaya çalışır. Yazara göre İngilizlerin ileri düzeyde bir sentez anlayışı vardır ve günümüz İngiliz medeniyetini bu sentez tecrübesi oluşturmuştur. Cumhuriyetçi söylem her ne kadar 
Batı ve Doğu sentezi üzerine kurulmuş olsa da tektipleşmeyi kanunlarla sabitleyen 1930'lar Türkiyesi için sentez takip edilmesi zor bir şiardır.

Türkiye'ye ilham olabilmesi için İngilizleri birleştiren şeyin peşine düşen Halide Edib, bu meseleyi özellikle Oxford'da, sınıfların ayrılması üzerine inşa edilmiş bir eğitim sisteminin tam orta yerinde anlamaya çalışır. Türkiye'yle hemen hemen hiç direkt bağlantı kurmayan Halide Edib, bu yazıda "vahdet" kelimesini kullanır. Fakat Halide Edib'in gözlemlediği kesret içinde vahdet, Türkiye'de uygulanan ve sekülerleştirmeden öte gidemeyen Tevhid-i Tedrisat Kanunu'nun etkilerinden çok farklıdır. "Oxford” başlıklı Akşam gazetesi yazısında İngiltere'deki eğitim ve sosyal hayatta görülen çeşitlilik içindeki vahdetten bahsederken, Halide Edib belki de Türkiye'nin cumhuriyetçi ideallerini kaybetmeden benzer bir yol tutabileceğini umut etmektedir:

Dışarıdan tedkik edenin gördüğü manzara İngilizlerin çok mürekkep bir millet olmasıdır. İngilize göre medeniyet terkiptir. İngilize göre bir milletin heyeti umumiyesinin içindeki vahdet, yalnız muhtelif kuvvet istidat ve düşüncüler arasından insicam teminile kabildir. Tenevvü içinde vahdet temin eden, müşterek çalışmak ve yaşamak yolunu gösteren sistem İngilize göre en uygun ve en yüksek bir sistemdir. Çünkü o medeniyeti terkipte buluyor; birörneklik, ergeç bir milleti iptidailiğe götüreceğine, ve iptidai ve basitlerin mürekkeplere mağlup olacağına inanıyor. İngiliz bu noktai nazarının isabetini isbat için saatlerce konuşur ve misallerini ekseri tabiatten alır, basit ve mürekkep hayvanların hayat sahasındaki mevkilerini, yaşamak kabiliyetlerini uzun uzadıya anlatır. Bana geliyor ki İngilizin (totaliter) rejimlere karşı -bunlar ister sağa, ister sola doğru olsun- adeta mistik haline gelen isyanının felsefesi sırf o rejimlerin insaniyeti basite doğru götürmesinden, birörneklik tevdi etmesinden ileri geliyor. (Halide Edib, 7 Temmuz, 1939, 7)

İngilizleri “çok mürekkep bir millet” olarak tanımlarken, tektipliğin bir milleti geri bırakacağını vurgularken Halide Edib Türkiye Cumhuriyeti'nin milletleşme politikalarını inceden inceye eleştiriyor olsa gerektir. İngiliz milletini okuyup, orada Türk milletine Osmanlı'dan miras kalmış olması gereken hasletleri görür. Halide Edib'in bu yaklaşımı ev sahibi - misafir hukukunun en iyi uygulandığı, Haswell ve Haswell'in, yukarıda da belirttiğim gibi “hediyeleşmek" olarak tespit ettiği anlardan biridir. Halide Edib'in İngiltere angajmanının son ayağı 1940'da İstanbul Üniversitesi'nin İngiliz Edebiyatı bölümünü kurması ve bölüm başkanlığı yapmasıdır. Çalışlar (2010) Mina Urgan ve Ayşe Cebesoy’un tanıklıklarıyla Halide Edib'in derslerini nasıl yürüttüğünü şöyle tasvir eder. "Öğrencilerine yönelttiği bir soruya aldığı tek cümlelik 'Fransa'da cumhuriyet vardır ama İngiltere'de hürriyet vardır,' yanıtı onun için çok kıymetli olabiliyordu.' (410) Halide Edib bu görev dahilinde Türkçe bir İngiliz Edebiyatı tarihi kaleme almış ve öğrencileriyle Shakespeare'in eserlerini çevirmiştir. Yazar bir bakıma İngiliz Edebiyatı'nı kendi evi yapmış ve içerisini de kendini ilgilendiren meselelerle döşemiştir. Halide Edib'in İngiltere ile olan ilişkisini belirleyen misafir - ev sahibi - işgalci kategorileri, sonunda söylemsel ve edebî düzlemde çocukluğundan beri okur-misafir 
olan Halide Edib'in ev sahibi-yazar olmasıyla sonuçlanmıştır. Halide Edib'in Akşam gazetesi yazılarının tümünü değerlendirdiğimizde yazarın İngilizlerin en çok parlamenter sisteminden, bireyselciliklerinden ve özgürlük geleneklerinden etkilendiğini ve bu geleneklerin Türkiye Cumhuriyeti için birer örnek oluşturabileceğini düşündüğünü görürüz. "Bir Alim ve Bazı Cereyanlar" başlıklı Akşam gazetesi yazısında milletler hakkında genellemeler yapmanın yanlış olacağını söyler, ama yine de İngiliz ruhu ve aklından bahseder. İngiliz edebiyatı ve dili Halide Edib'e kariyerinin sonuna kadar eşlik edecektir. Bu eşliğin ev sahipliği ve misafirlik arasında gidip geldiğinin yazar da farkındadır ve "misafir-okuyucu" olarak bu iki duruşunun da hakkını vermeye çalışır:

Hiç bir millet için değil, hatta bir ferd için bile şunu yapar, şunu yapmaz, diye toptan hüküm vermenin yanlış olduğunu anlıyacak kadar uzun yaşadım, tecrübe gördüm ve gördüklerimi gönlüme göre tefsir değil, oldukları gibi muhakeme etmeye çalıştım. Onun için İngilizler için de kehaneti doğru bulmam. Fakat yakından tanıdığım bir kaç çok samimi İngiliz komünisti de dahil olmak şartile, liberal, muhafazakar, sosyalist, hulasa her renkte İngilizin ve bütün İngilizliğin en çok müdafaa edeceği kıymet ne olduğu hakkında düşünülürse bu milletin mahdud bile olsa ferd hürriyeti denilen şey olduğuna inanmak lazım geliyor. (Halide Edib, 20 Temmuz 1939, 7)

Akşam gazetesi yönetimi ve Türkiye akademisi her ne kadar Halide Edib'e çoktan İngiltere konusunda ev sahibi - yazar payesi vermiş olsa da yazar burada ev sahibinin misafirperverliğini kötüye kullanmak istemeyen bir misafir-okur tavrı takınmaktadır. Bu tavrın ne kadar retorik, ne kadar içten olduğunun kararını da okuyucu verecektir. Önemli olan Halide Edib'in yazıyı vermek istediği mesajı vererek bitirmiş olmasıdır.

\section{SONUÇ}

İngilizler Halide Edib'in edebî tahayyülünde, mürebbiyesinin anlattığı hikâyelerle başlamak üzere, başından beri önemli bir yer tutmuştur. Yazarın biyografisi de İngiltere ile sürekli bir alışverişe işaret eder. İstanbul'da başladığı yazın hayatı, İngiltere'deki dergilere gönderdiği yazılar sayesinde uluslararası bir boyut kazanmış ve bu edebî çerçeve içerisinde devam etmiştir. İngiltere ve Türkiye arasındaki ilişki yıllar içinde çeşitli şekiller alırken, Halide Edib'in İngilizleri tasvir şekli edebî ve siyasi hayatının başından beri belirli bir istikrar gösterir. Yazar The Turkish Ordeal' da bile İngilizlerle olan mücadelesinin en önemli akşamında, İngiliz polisler meclisi basmaya hazırlanırken bu tecavüzün yanlışlığına işaret edip, bir yandan da İngiliz parlamentosuna gönderme yapabilmektedir.

Yazarın İngiltere hakkındaki bilgisinin yanında savaş ve sürgün hayatının değiştirdiği güç dengeleri bu ülke ile arasında oldukça girift bir ev sahibi -misafï - işgalci ilişkisi yaratır. İşgalci İngilizlerin şiddetiyle karşılaştığında edebiyatından beslendiği bu ülkenin askeri ve diplomatik güçlerini yerden yere vurmaktan çekinmez. Metinler bağlamında ev sahibi, askeri bağlamda işgalci, entelijansiyası bağlamında tekrar ev sahibi olarak tanıdığı İngilizler 1930'larda Halide Edib'in yazın hayatında Türkiye için kurumlarıyla model oluşturabilecek 
bir millet olarak kendini gösterir. Nitekim Akşam gazetesi yazı dizisinin başında da yazar -her ne kadar çekinceleri olsa da- İngiltere'den "müttefik" olarak bahsetmek durumundadır. Haswell ve Haswell'in tanımladığı metinler ve ülkelerin “okunması” esnasında oluşan ev sahibi, misafir ve işgalci konumlarına Halide Edib ve İngiltere bağlamında müttefik ve/veya rol model konumlarını eklemek gerekecektir.

İngilizlerin ona kattıklarının hakkını verirken onları eleştirmeye devam etmesi gibi, yazarın öngördüğü yol planından sapmış olsa da Halide Edib cumhuriyet projesinin de daima arkasındadır. Sürgünde dahi yeni Türkiye'nin savunucusu olan Halide Edib, cumhuriyetin kurucusuyla düştüğü fikir ayrılığına rağmen kendi aydın konumundan hiçbir zaman şüphe duymaz ve Atatürk öldüğünde ülkesine geri dönüp bıraktığ yerden fikir hayatındaki rolüne devam eder. Ev sahibi, misafir ve işgalci kategorileri üzerine düşünmüş ve yazmış olan Halide Edib hayatı boyunca değişen dünyada kendi durduğu yerden her zaman emindir: Kozmopolit Osmanlı, uluslararası bilgi cumhuriyetinin bir üyesi ve kültürler ve edebiyatlar mütercimi bir entelektüel.

Finansal Destek: Yazar bu çalışma için finansal destek almamıştır.

\section{KAYNAKÇA}

Adıvar, H. E. (1997 [1922]). Ateşten gömlek. İstanbul: Özgür Yayınları.

Halide Edib. (1937). Inside India. London: George Allen and Unwin Ltd.

Halide Edib. (tarihsiz) The Turkish ordeal. Erişim adresi: http://louisville.edu/a-s/history/turks/ Turkish\%20Ordeal.pdf

Halide Edib. (1939, 24 Ağustos). Köy ve komşular. Akşam, s. 7

Halide Edib. (1939, 10 Haziran). Manş denizini geçerken. Akşam, s. 7

Halide Edib. (1939, 26 Temmuz). Parlamentolar anası. Akşam, s. 7

Halide Edib. (1939, 27 Haziran). İnsan ve zihniyet portresi. Akşam, s. 7

Halide Edib. (1939, 7 Temmuz). Oxford. Akşam. s. 7

Halide Edib. (1939, 20 Temmuz). Bir alim ve bazı cereyanlar. s. 7

Çalışlar, İ. (2010). Halide Edib: Biyografisine sığmayan kadın. Istanbul: Everest.

Durakbaşa, A. (2000) Halide Edib: Türk modernleşmesi ve feminizm. Istanbul: İletişim.

Enginün, İ. (1978). Halide Edib Adlvar'ın eserlerinde doğu ve batı meselesi. İstanbul: Üniversitesi Edebiyat Fakültesi.

Forbes, R. (1926, 7 Şubat). Two women contend for a new eden in the East. The New York Times, s. SM4 Haswell J. and R. Haswell (2010). Hospitality and authoring. Colorado: University Press Colorado.

Price, C. (1928, 29 Temmuz). A woman speaks for the New Turkey. The New York Times, s. SM4

Saydun, Z. B. (2008) Construction of nationalism and gender in Halide Edib's autobiographical writings. Trier: Wissenschaftlicher Verlag Trier.

Streit, C. K. (1928, 14 Ekim). Halide Hanum recites the epic of Turkey's revival: her second volume. New York Times, s. A9

Toynbee, A. (1967). Acquaintances. London: Oxford UP. 